\title{
PENERAPAN PROTOKOL PENCEGAHAN COVID-19 DALAM PELAKSANAAN PROYEK KONSTRUKSI
}

(Studi Kasus Proyek Gedung dan Jalan di Surakarta)

\author{
Herman Susila \\ Program Studi Teknik Sipil, Fakultas Teknik, Universitas Tunas Pembangunan \\ hermansusila73@gmail.com \\ Reki Arbianto \\ Program Studi Teknik Sipil, Fakultas Teknik, Universitas Tunas Pembangunan \\ reki.arbianto@lecture.utp.ac.id
}

\begin{abstract}
Abstrak
Penyebaran virus covid-19 di Indonesia sangat begitu cepat, sehingga pemerintah mengeluarkan status keadaan tertentu darurat bencana wabah penyakit akibat corona virus dan berupaya untuk menekan penyebaran virus tersebut. Langkah pencegahan penyebara covid-19 juga dilakukan di bidang jasa konstruksi. Pemerintah melalui menteri PUPR mengeluarkan Instruksi Menteri No. 02/IN/M/2020 tentang Protokol Pencegahan Penyebaran Corona Virus Disease 2019 (Covid-19) Dalam Penyelenggaraan Jasa Konstruksi. Masalah yang timbul adalah bagaimana penerapan protokol pencegahan COVID-19 dalam pelaksanaan proyek konstruksi. Penelitian ini bertujuan untuk mengetahui sejauh mana penerapan protokol pencegahan COVID-19 dalam pelaksanaan proyek konstruksi di Surakarta. Penelitian dilakkukan dengan metode deskriptif. Data diambil melalui pengamatan langsung di lapangan dan wawancara dengan questioner. Dari hasil analisis didapat bahwa $60 \%$ proyek sudah ada satgas covid-19 dan melaksanakan identifikasi potensial bahaya covid-19 di lapangan. Penyediaan fasilitas kesehatan pada tempat pekerjaan konstruksi termasuk dalam kategori baik dengan nilai mean 1,67. Penerapan Pencegahan Covid-19 dalam pelaksanaan konstruksi termasuk dalam kategori baik dengan nilai mean 1,69.
\end{abstract}

Kata kunci: konstruksi, covid-19, K3

\begin{abstract}
The spread of the covid-19 virus in Indonesia is so fast, that the government has issued a certain state of emergency for a disease outbreak due to the corona virus and is trying to suppress the spread of the virus. Measures to prevent the spread of covid19 are also being carried out in the field of construction services. The government through the PUPR minister issued Ministerial Instruction No. 02 / IN / M / 2020 concerning the Protocol to Prevent the Spread of Corona Virus Disease 2019 (Covid19) in the Implementation of Construction Services. The problem that arises is how to implement the COVID-19 prevention protocol in the implementation of construction projects. This study aims to determine the extent to which the COVID-19 prevention protocol is implemented in the implementation of construction projects in Surakarta. The research was carried out using descriptive methods. Data were collected through direct observation in the field and interviews with questioners. From the results of the analysis, it was found that $60 \%$ of the projects already had a Covid-19 task force and carried out identification of the potential dangers of Covid-19 in the field. The provision of health facilities at construction work sites is in the good category with a mean value of 1.67. The application of Covid-19 Prevention in construction is in the good category with a mean value of 1.69 .
\end{abstract}

Keywords: construction, covid-19, K3 


\section{Pendahuluan}

\section{A. Latar Belakang}

Awal tahun 2020 sebagian besar negara di dunia telah di landa wabah Corona Virus Desease 2019 (Covid-19) . Wabah ini muncul pertama kali di kota Wuhan, China. Virus ini telah menyebar dengan cepat ke berbagai negara termasuk Indonesia. Olehkarena itu Organisasi Kesehatan Dunia (WHO) pada tanggal 11 Maret 2020 secara resmi mengumumkan wabah Covid-19 sebagai pandemi global.

Di Indonesia penyebaran virus begitu cepat sehingga BNPB menetapkan Status Keadaan Tertentu Darurat Bencana Wabah Penyakit Akibat Virus Corona. Selanjutnya upaya yang dilakukan pemerintah untuk menekan penyebaran virus adalah pemerintah menetapkan Peraturan Pemerintah tentang Pembatasan Sosial Berskala Besar (PSBB) dan Keppres penetapan kedaruratan masyarakat (Sari H.M, 2020). Langkah pencegahan penyebara covid-19 juga dilakukan di bidang jasa konstruksi. Pemerintah melalui menteri PUPR mengeluarkan Instruksi Menteri No. 02/IN/M/2020 tentang Protokol Pencegahan Penyebaran Corona Virus Disease 2019 (Covid19) Dalam Penyelenggaraan Jasa Konstruksi yang berlaku mulai tanggal 27 Maret 2020. Salah satu hal yang diinstruksikan menteri adalah melaksanakan protocol pencegahan COVID-19 dalam penyelenggaraan Jasa Konstruksi.

\section{B. Rumusan Masalah}

Bagaimana penerapan protokol pencegahan
COVID-19 dalam pelaksanaan proyek konstruksi di Surakarta?

\section{Tujuan Penelitian}

Penelitian ini bertujuan untuk mengetahui sejauh mana penerapan protokol pencegahan COVID-19 dalam pelaksanaan proyek konstruksi di Surakarta.

\section{LANDASAN TEORI}

\section{A. Keselamatan dan Kesehatan Kerja}

Filosofi dari keselamatan dan kesehatan kerja (K3) adalah sebagai pemikiran dan upaya manusia untuk menjamin keutuhan dan kesempurnaan baik jasmani maupun rohani, hasil karya dan budayanya untuk kemakmuran dan kesejahteraan manusia pada umumnya dan tenaga kerja pada khususnya. Keselamatan dan kesehatan kerja ditinjau dari keilmuan merupakan ilmu pengetahuan dan penerapannya dalam upaya mencegah kemungkinan terjadinya kecelakaan dan penyakit akibat kerja (Armanda dalam Kani B.R. et.all, 2013). Keselamatan kerja adalah keselamatan yang berhubungan dengan mesin, alat kerja, bahan dan proses pengolahannya, landasan tempat kerja dan lingkungannya serta cara-cara melakukan pekerjaan (Triyanto dalam Susila, 2019). Sedangkan Kesehatan kerja adalah suatu keadaan atau kondisi badan/tubuh yang terlindungi dari segala ancaman atau gangguan yang diakibatkan oleh pekerjaan yang dilaksanakan (Milen dalam Susila, 2019).

Jasa konstruksi merupakan industri dengan tingkat bahaya yang tinggi. Oleh karena itu pemerintah mewajibkan adanya keselamatan 
dan keselamatan kerja (K3) konstruksi atau sistem manajemen keselamatan dan kesehatan kerja (SMK3) diperusahaan konstruksi (Parinduri L dan Parinduri T, 2020). Dengan adanya K3 konstruksi atau SMK3 diharapkan dapat meningkatkan efektifitas perlindungan keselamatan kesehatan kerja dan mencegah serta mengurangi kecelakaan kerja dan penyakit akibat kerja. (Parinduri L dan Parinduri T, 2020).

\section{B. Pencegahan Covid-19 dalam}

\section{Penyelenggaraan Konstruksi}

Kegiatan konstruksi melibatkan sumberdaya manusia yang relative banyak. Interaksi antar tenaga kerja tidak mungkin untuk dihindari. Hal ini sangat rentan untuk penyebaran penyakit seperti penyebaran Covid-19. Usaha yang dilakukan untuk pencegahan penyebaran Covid19 dalam pelaksanaan konstruksi mengacu pada instruksi menteri PUPR No. 02/IN/M/2020 tentang Protokol Pencegahan Penyebaran Corona Virus Disease 2019 (Covid-19) Dalam Penyelenggaraan Jasa Konstruksi. Adapun skema protokol pencegahan penyebaran covid19 dalam Penyelenggaraan jasa konstruksi adalah sbb:

\section{Pembentukan satuan tugas (satgas) pencegahan covid-19}

Satgas dibentuk oleh Pejabat Pembuat Komitmen (PPK) berjumlah paling sedikit 5 (lima) orang, terdiri dari 1 (satu) ketua merangkap anggota dan 4 (empat) mewakili pengguna jasa dan penyedia jasa. Tugas, tanggungjawab kewenangan satgas adalah melakukan:

- Sosialisasi

- Pembelajaran (edukasi)

- Promosi teknik

- Metode/pelaksanaan pencegahan covid-19 di lapangan

- Pemeriksaan kesehatan terkait potensi terinfeksi covid-19 kepada semua pekerja dan tamu proyek

- Pemantauan kondisi kesehatan pekerja dan pengendalian mobilisasi/demobilisasi pekerja

- Pemberian vitamin dan nutrisi tambahan guna peningkatan imunitas pekerja

- Pengadaan fasilitas lapangan

- Melaporkan kepada PPK dalam hal telah ditemukan pekerja yang positif dan/atau berstatus pasien dalam pengawasa (PDP) dan merekomendasikan dilakukan penghentian kegiatan sementara

2. Identifikasi bahaya covid-19 di lapangan

a. Stgas pencegahan covid-19 berkoordinasi dengan satgas penanggulangan covid-19 Kementerian PUPR untuk menentukan:

- Identifikasi potensi risiko proyek terhadap pusat sebaran penyebaran covis-19 di daerah yang bersangkutan.

- Kesesuaian fasilitas kesehatan di lapangan dengan protocol penanganan covid-19 yang dikeluarkan oleh pemerintah.

- Tindak lanjut terhadap Penyelenggaraan Jasa Konstruksi

b. Dalam hal Penyelenggaraan Jasa Konstruksi tersebut teridentifikasi: 
- Memiliki resiko tinggi akibat lokasi proyek berada di pusat sebaran.

- Telah ditemukan pekerja yang positif dan/atau berstatus orang dalam pengawasan (PDP); atau

- Pimpinan

Kementerian/Lembaga/Instansi/Kepala daerah telah mengeluarkan peraturan untuk menghentikan kegiatan sementara akibat keadaan kahar;

Maka Penyelenggaraan Jasa Konstruksi tersebut dapat diberhentikan sementara akibat kahar.

3.Penyediaan fasilitas kesehatan di lapangan

- Penyedia Jasa Konstruksi wajib menyediakan ruang klinik kesehatan di lapangan yang dilengkapi dengan sarana kesehatan yang memadai, antara lain tabung oksigen, pengukur suhu badan nirsentuh (thermoscan), pengukur tekanan darah, obat-obatan dan petugas medis.

- Penyedia Jasa Konstruksi wajib memiliki kerjasama operasional perlindungan kesehatan dan pencegahan covid-19 dengan rumah rumah sakit dan/atau puskesmas terdekat untuk tindakan darurat.

- Penyedia Jasa Konstruksi wajib menyediakan fasilitas tambahan, antaralain: pencuci tangan (air, sabun dan hand sanitizer), tisu, masker dikantor dan lapangan bagi seluruh pekerja dan tamu.

- Penyedia Jasa Konstruksi wajib menyediakan vaksin, vitamin dan nutrisi tambahan guna peningkatan imunitas pekerja.

4. Pelaksanaan Pencegahan Covid-19 di Lapangan.

- Satgas pencegahan covid-19 memasng poster (flyers) baik digital maupun fisik tentang himbauan/anjuran pencegahan covid-19 untuk disebarluaskan atau dipasang di tempat-tempat strategis di lokasi proyek.

- Satgas pencegahan covid-19 bersama petugas medis harus menyampaikan penjelasan,o anjuran, kampanye, promosi teknik pencegahan covid-19 dalam setiap kegiatan penyuluhan K3 pagi hari (safety morning talk)

- Petugas medis bersama para Satuan Pengaman (security staff) melaksanakan pengukuran suhu tubuh kepada seluruh pekerja, dan karyawan setiap pagi,siang, dan sore.

- Satgas pencegahan covid-19 melarang orang (seluruh pekerja dan tamu) yang terindikasi memiliki suhu tubuh $\geq 38$ derajat celcius dating ke lokasi pekerja.

- Apabila ditemukan pekerja di lapangan sebagai Pasien Dalam Pengawasan (PDP) covid-19, pekerja harus diberhentikan sementara oleh pengguna jasa dan/atau penyedia jasa paling sedikit 14 hari kerja.

- Petugas medis dibantu Satuan Pengaman (security staff) melakukan evakuasi dan penyemprotan disinfektan pada seluruh tempat, fasilitas dan peralatan kerja. 
- Penghentian sementara dilakukan hingga proses evakuasi dan penyemprotan disinfektan, serta pelaksanaan pemeriksaan kesehatan dan isolasi tenaga kerga yang pernah melakukan kontak fisik dengan tenaga kerja yang terpapar telah selesai.

\section{METODE PENELITIAN}

\section{A. Rancangan Penelitian}

Metode yang digunakan dalam penelitian ini adalah dengan metode deskriptif. Tujuan dari penelitian deskriptif ini adalah untuk menggambarkan pelaksanaan pencegahan penyebaran covid-19 pada saat pelaksanaan kontruksi.

\section{B. Populasi Dan Sampel}

Populasi dalam penelitian ini adalah proyekproyek yang ada di wilayah Solo Raya dan sampel diambil dengan random sampling.

\section{Pengumpulan Data}

Teknik pengumpulan data dalam penelitian ini adalah dengan cara:

- Observasi/ pengamatan dilapangan

- Mengadakan wawancara

- Penyebaran kuesioner

\section{Analisis Data}

analisis data dilakukan dengan cara menyusun, membahas dan mengevaluasi datadata kuesioner dan hasil wawancara maupun observasi mengenai pelaksanaan pencegahan covid-19 dalam pelaksanaan proyek konstruksi. Proses analisis data menggunakan software SPSS dan exel.

Pengukuran terhadap variable pelaksanaan pencegahan penyebaran covid-19 dalam pelaksanaan konstruksi ini menggunakan pilihan ya atau tidak. Untuk mendapatkan hasil, pengukuran, jawaban diubah menjadi skala ordinal dengan nilai ya $=2$ dan tidak $=1$. Selanjutnya data ordinal diubah menjadi data interval. Interval dibuat tiga kelas yaitu kurang, cukup dan baik. Besarnya interval adalah:

interval $=\frac{\text { nilai maksimum }- \text { nilai minimum }}{\text { jumlah } \text { kelas }}$ $=\frac{1}{3}=0.33$

Skala distribusi penilaian adalah sbb:

Kurang $=1,00-1,33$

Cukup $=1,34-1,66$

Baik $=1,67-2,00$

\section{HASIL DAN PEMBAHASAN}

\section{A. Gambaran Obyek Penelitian}

Dari hasil penelitian Penanganan Pencegahan Penyebaran Cofid-19 dalam Pelaksanaan Proyek Konstruksi di Surakarta dari data sampel yang berjumlah 10 proyek diperoleh gambaran bahwa obyek penelitian terdiri dari 5 proyek atau $50 \%$ proyek gedung dan 5 proyek atau 50\% proyek jalan. Gambaran nilai proyek dari hasil penelitian didapat $20 \%$ dengan nilai $\leq 2,5 \mathrm{M}$ dan $80 \%$ dengan nilai proyek $>2,5 \mathrm{M}-50 \mathrm{M}$. Hal ini berarti hasil penelitian merupakan perspektif dari pekerjaan konstruksi dengan 
kualifikasi menengah.

\section{B. Penerapan Pencegahan Covid-19 dalam Pelaksanaan Konstrusi}

Penilaian penerapan pencegahan covid-19 dalam pelaksanaan konstruksi adalah dengan menggunakan ceklist. Berikut tabel 1 hasil ceklist penanganan pencegahan penyebaran covid-19 dalam pelaksanaan konstruksi di Surakarta.

Tabel 1.

Ceklist pelaksanaan protocol pencegahan penyebaran covid-19 dalam pelaksanaan konstruksi di Surakarta

\begin{tabular}{|c|c|c|c|c|}
\hline Faktor & $\begin{array}{l}\mathbf{N} \\
\mathbf{o}\end{array}$ & Pertanyaan & $\mathbf{Y a}$ & $\begin{array}{c}\text { Tida } \\
\mathbf{k}\end{array}$ \\
\hline $\begin{array}{l}\text { Pembentukan } \\
\text { Satgas } \\
\text { Covid-19 }\end{array}$ & 1 & $\begin{array}{l}\text { Apakah terdapat satuan } \\
\text { tugas (satgas)/tim untuk } \\
\text { pencegahan covid-19? }\end{array}$ & 6 & 4 \\
\hline $\begin{array}{l}\text { Identifikasi } \\
\text { bahaya } \\
\text { covid-19 di } \\
\text { lapangan }\end{array}$ & 2 & $\begin{array}{l}\text { Apakah satgas/tim } \\
\text { pencegahan covid-19 } \\
\text { telah melakukan } \\
\text { identivikasi potensi } \\
\text { bahaya covid-19 di } \\
\text { lapangan? }\end{array}$ & 6 & 4 \\
\hline \multirow{11}{*}{$\begin{array}{l}\text { Penyediaan } \\
\text { fasilitas } \\
\text { kesehatan di } \\
\text { lapangan }\end{array}$} & 3 & $\begin{array}{l}\text { Apakah penyedia jasa } \\
\text { menyediakan fasilitas } \\
\text { pencegahan covid-19? }\end{array}$ & 7 & 3 \\
\hline & 4 & $\begin{array}{l}\text { Apakah penyedia jasa } \\
\text { menyediakan ruangan } \\
\text { klinik kesehatan di } \\
\text { lapangan/proyek? }\end{array}$ & 5 & 5 \\
\hline & 5 & $\begin{array}{l}\text { Apakah terdapat sarana } \\
\text { kesehatan seperti tabung } \\
\text { oxygen? }\end{array}$ & 5 & 5 \\
\hline & 6 & $\begin{array}{l}\text { Apakah terdapat sarana } \\
\text { kesehatan seperti } \\
\text { thermoscan? }\end{array}$ & 6 & 4 \\
\hline & 7 & $\begin{array}{l}\text { Apakah terdapat sarana } \\
\text { kesehatan seperti obat- } \\
\text { obatan? }\end{array}$ & 9 & 1 \\
\hline & 8 & $\begin{array}{l}\text { Apakah terdapat sarana } \\
\text { kesehatan seperti tenaga } \\
\text { medis? }\end{array}$ & 4 & 6 \\
\hline & 9 & $\begin{array}{l}\text { Apakah penyedia jasa } \\
\text { menyediakan fasilitas: } \\
\text { pencuci tangan } \\
\text { (wastafel)? }\end{array}$ & 10 & 0 \\
\hline & 10 & $\begin{array}{l}\text { Apakah penyedia jasa } \\
\text { menyediakan fasilitas: } \\
\text { sabun? }\end{array}$ & 9 & 1 \\
\hline & 11 & $\begin{array}{l}\text { Apakah penyedia jasa } \\
\text { menyediakan fasilitas: } \\
\text { hand sanitizer? }\end{array}$ & 7 & 3 \\
\hline & 12 & $\begin{array}{l}\text { Apakah penyedia jasa } \\
\text { menyediakan fasilitas: } \\
\text { tissue? }\end{array}$ & 7 & 3 \\
\hline & 13 & $\begin{array}{l}\text { Apakah penyedia jasa } \\
\text { menyediakan fasilitas: }\end{array}$ & 7 & 3 \\
\hline
\end{tabular}

\begin{tabular}{|c|c|c|c|c|}
\hline & & masker? & & \\
\hline & 14 & $\begin{array}{l}\text { Apakah penyedia jasa } \\
\text { menyediakan vitamin } \\
\text { dan nutrisi bagi pekerja } \\
\text { dan karyawan? }\end{array}$ & 4 & 6 \\
\hline & 15 & $\begin{array}{l}\text { Apakah penyedia jasa } \\
\text { melakukan kerjasama } \\
\text { dengan rumah sakit atau } \\
\text { puskesmas setempat } \\
\text { terkait penanganan } \\
\text { covid-19? }\end{array}$ & 8 & 2 \\
\hline \multirow[t]{11}{*}{$\begin{array}{l}\text { Pelaksanaan } \\
\text { Pencegahan } \\
\text { Covid-19 di } \\
\text { Lapangan }\end{array}$} & 16 & $\begin{array}{l}\text { Apakah di lokasi proyek } \\
\text { terdapat spanduk/poster } \\
\text { di tempat-tempat } \\
\text { strategis terkait covid-19 } \\
\text { (jaga jarak, gunakan } \\
\text { masker, sering cuci } \\
\text { tangan dan lain-lain)? }\end{array}$ & 9 & 1 \\
\hline & 17 & $\begin{array}{l}\text { Apakah setiap hari (pagi) } \\
\text { dilakukan } \\
\text { penyuluhan/safty } \\
\text { morning talk kepada } \\
\text { semua tenaga kerja } \\
\text { untuk menjaga diri dari } \\
\text { covid-19? }\end{array}$ & 5 & 5 \\
\hline & 18 & $\begin{array}{l}\text { Apakah setiap hari } \\
\text { terdapat pengukuran } \\
\text { suhu terhadap semua } \\
\text { tenaga kerja? }\end{array}$ & 4 & 6 \\
\hline & 19 & $\begin{array}{l}\text { Apakah sudah dilakukan } \\
\text { penyemprotan } \\
\text { desinfektan secara } \\
\text { berkala terhadap tempat } \\
\text { kerja dan peralatan kerja } \\
\text { ? }\end{array}$ & 5 & 5 \\
\hline & 20 & $\begin{array}{l}\text { Apakah tenaga kerja } \\
\text { mengganti dan mencuci } \\
\text { seluruh pakaian kerja } \\
\text { setiap hari dengan } \\
\text { sabun? }\end{array}$ & 7 & 3 \\
\hline & 21 & $\begin{array}{l}\text { Apakah APD (Alat } \\
\text { Pelindung Diri) selalu } \\
\text { dibersihkan dan tidak } \\
\text { dipakai/dipinjamkan } \\
\text { oleh orang lain? }\end{array}$ & 9 & 1 \\
\hline & 22 & $\begin{array}{l}\text { Apakah kantor lapangan } \\
\text { (direksi keet) dan } \\
\text { peralatan di dalamnya } \\
\text { (monitor, laptop, } \\
\text { keyboard dll) selalu } \\
\text { dibersihkan? }\end{array}$ & 9 & 1 \\
\hline & 23 & $\begin{array}{l}\text { Apakah tenaga kerja } \\
\text { dianjurkan untuk } \\
\text { istirahat yang cukup dan } \\
\text { makan makanan yang } \\
\text { bergizi? }\end{array}$ & 9 & 1 \\
\hline & 24 & $\begin{array}{l}\text { Apakah sudah ada } \\
\text { tenaga kerja yang } \\
\text { terindikasi terpapar } \\
\text { covid-19? }\end{array}$ & 1 & 9 \\
\hline & 25 & $\begin{array}{l}\text { Jika ada tenaga kerja } \\
\text { yang terindikasi terpapar } \\
\text { covid-19, apakah } \\
\text { pekerjaan dihentikan } \\
\text { sementara? }\end{array}$ & 7 & 3 \\
\hline & 26 & $\begin{array}{l}\text { Jika ada tenaga kerja } \\
\text { yang terindikasi terpapar } \\
\text { covid-19, apakah } \\
\text { penyedia jasa melakukan }\end{array}$ & 9 & 1 \\
\hline
\end{tabular}




\begin{tabular}{|l|l|l|l|l|}
\hline & $\begin{array}{l}\text { isolasi bagi tenaga kerja } \\
\text { yang terpapar covid-19? }\end{array}$ & & \\
\cline { 2 - 5 } 27 & $\begin{array}{l}\text { Jika ada tenaga kerja } \\
\text { yang terindikasi terpapar } \\
\text { covid-19, apakah } \\
\text { penyedia jasa melakukan } \\
\text { penyemprotan } \\
\text { desinfektan pada sarana } \\
\text { dan prasarana kantor? }\end{array}$ & 9 & 1 \\
\hline
\end{tabular}

Dari hasil analisis didapat bahwa $60 \%$ proyek sudah ada satgas covid-19 dan melaksanakan identifikasi potensial bahaya covid-19 di lapangan. Tabel 2 menunjukkan hasil analisis mean untuk faktor Penyediaan Fasilitas Kesehatan di lapangan.

Tahel 2.

Descriptive Statistics Penyediaan fasilitas kesehatan di

\begin{tabular}{|c|c|c|c|c|}
\hline & $\mathrm{N}$ & $\begin{array}{c}\text { lapangan } \\
\text { Minimu } \\
\mathrm{m}\end{array}$ & Maximum & Mean \\
\hline $\mathrm{C} 1$ & 10 & 1.00 & 2.00 & 1.7000 \\
\hline $\mathrm{C} 2$ & 10 & 1.00 & 2.00 & 1.5000 \\
\hline C3 & 10 & 1.00 & 2.00 & 1.4000 \\
\hline $\mathrm{C} 4$ & 10 & 1.00 & 2.00 & 1.6000 \\
\hline C5 & 10 & 1.00 & 2.00 & 1.9000 \\
\hline C6 & 10 & 1.00 & 2.00 & 1.4000 \\
\hline $\mathrm{C} 7$ & 10 & 2.00 & 2.00 & 2.0000 \\
\hline $\mathrm{C} 8$ & 10 & 1.00 & 2.00 & 1.9000 \\
\hline C9 & 10 & 1.00 & 2.00 & 1.7000 \\
\hline $\mathrm{C} 10$ & 10 & 1.00 & 2.00 & 1.7000 \\
\hline C11 & 10 & 1.00 & 2.00 & 1.7000 \\
\hline $\mathrm{C} 12$ & 10 & 1.00 & 2.00 & 1.4000 \\
\hline $\mathrm{C} 13$ & 10 & 1.00 & 2.00 & 1.8000 \\
\hline $\begin{array}{l}\text { Valid N } \\
\text { (listwise) }\end{array}$ & 10 & & & \\
\hline
\end{tabular}

Dari perhitungan nilai mean gabungan untuk faktor Penyediaan Fasilitas Kesehatan di lapangan diperoleh nilai mean 1,67. Hal ini berarti bahwa penyediaan fasilitas kesehatan pada tempat pekerjaan konstruksi termasuk dalam kategori baik. Fasilitas kesehatan pada tempat pekerjaan konstruksi ini merupakan bentuk upaya untuk menjamin tenaga kerja terhindar dari penyakit khususnya covid-19, sehingga kegiatan proyek tidak terganggu.

Hasil analisis mean terhadap Penanganan Pencegahan Covid-19 di Lapangan ditunjukkan pada table 3 .

Tabel 3.

Descriptive Statistics penanganan pencegahan covid-19 di lapangan

\begin{tabular}{|c|c|c|c|c} 
& $\mathrm{N}$ & Minimum & Maximum & Mean \\
\hline D1 & 10 & 1.00 & 2.00 & 1.9000 \\
\hline D2 & 10 & 1.00 & 2.00 & 1.5000 \\
\hline D3 & 10 & 1.00 & 2.00 & 1.4000 \\
\hline D4 & 10 & 1.00 & 2.00 & 1.5000 \\
\hline D5 & 10 & 1.00 & 2.00 & 1.7000 \\
\hline D6 & 10 & 1.00 & 2.00 & 1.9000 \\
\hline D7 & 10 & 1.00 & 2.00 & 1.9000 \\
\hline D8 & 10 & 1.00 & 2.00 & 1.9000 \\
\hline D9 & 10 & 1.00 & 2.00 & 1.1000 \\
\hline D10 & 10 & 1.00 & 2.00 & 1.7000 \\
\hline D11 & 10 & 1.00 & 2.00 & 1.9000 \\
\hline D12 & 10 & 1.00 & 2.00 & 1.9000 \\
\hline Valid N & 10 & & & \\
\hline (listwise) & & & & \\
\hline & & & & \\
\hline
\end{tabular}

Dari perhitungan nilai mean gabungan untuk faktor Penerapan Pencegahan Covid-19 di Lapangan diperoleh mean 1,69. Hal ini berarti bahwa Penerapan Pencegahan Covid-19 di Lapangan termasuk dalam kategori baik. Pencegahan covid-19 dalam proyek konstruksi agar berjalan efektif maka harus menggunakan prosedur yang baik. Menteri PUPR dalam hal ini sudah mengeluarkan instruksi No. 02/IN/M/2020 tentang Protokol Pencegahan Penyebaran Corona Virus Disease 2019 (Covid19) dalam Penyelenggaraan Jasa Konstruksi. 
Mekanisme Protokol Pencegahan Penyebaran Corona Virus Disease 2019 (Covid-19) dalam Penyelenggaraan Jasa Konstruksi adalah sebagai berikut:

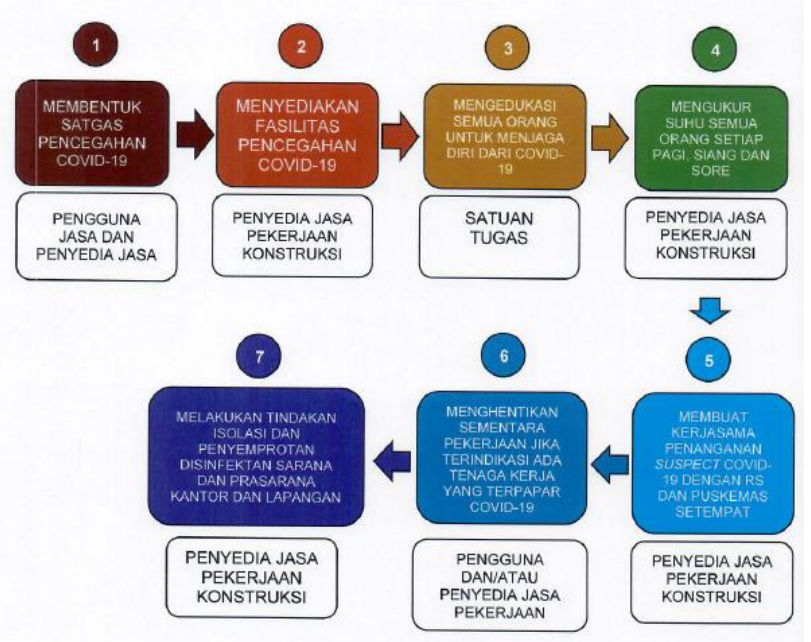

Gambar 1.

Protokol Pencegahan Penyebaran Corona Virus Disease 2019 (Covid-19) dalam Penyelenggaraan Jasa Konstruksi

\section{KESIMPULAN}

Mekanisme pencegahan penyebaran covid-19 dalam pelaksanaan pekerjaan konstruksi sudah diatur oleh pemerintah dalam instruksi menteri PUPR No. 02/IN/M/2020. Semua pelaku dalam penyelenggaraan konstruksi harus menjalankan prosedur atau mekanisme yang sudah ditetapkan agar keselamatan tenaga kerja dan semua yang terlibat dalam penyelenggaraan konstruksi tehindar dari wabah covid-19.

Penelitian Penerapan Protokol Pencegahan Covid-19 Dalam Pelaksanaan Proyek Konstruksi ini dilakukan pada proyek-proyek gedung dan jalan di Surakarta. Dari hasil analisis dapat diambil kesimpulan bahwa sebesar $60 \%$ sudah terdapat satgas covid-19 dan telah melakukan identifikasi potensial bahaya covid-19 di lapangan. Kontraktor dalam menyediaan fasilitas kesehatan di tempat pekerjaan termasuk dalam kategori baik, kontraktor juga sudah menerapkan Protokol Pencegahan Covid-19 di tempat pekerjaan dengan baik.

\section{DAFTAR PUSTAKA}

Instruksi Menteri Pekerjaan Umum dan PUPR Nomor 2/IN/M/2020 tentang Protokol Pencegahan Penyebaran Coronavirus Disease 2019 (COVID-19) Dalam Penyelenggaraan Jasa Konstruksi.

Kani, B. R., Mandagi, R. J., p Rantung, J., \& Malingkas, G. Y. (2013). Keselamatan Dan Kesehatan Kerja Pada Pelaksanaan Proyek Konstruksi (Studi Kasus: Proyek Pt. Trakindo Utama). Jurnal Sipil Statik, 1(6).

Parinduri, L., \& Parinduri, T. (2020). Implementasi Manajemen Keselamatan Konstruksi Dalam Pandemi Covid 19. Buletin Utama Teknik, 15(3), 222-228.

Susila, H. (2019). Pelaksanaan K3 Pada Proyek Pembangunan Interchange Boyolali. Jurnal Teknik Sipil dan Arsitektur, 24(1). 